\title{
Financial stability of investment and construction projects in terms of project financing
}

\author{
Marina Mishlanova ${ }^{1, *}$ \\ ${ }^{1}$ Moscow State University of Civil Engineering, Yaroslavskoye sh., 26, Moscow, 129337, Russia
}

\begin{abstract}
The paper determines the relevance and purpose of the study. The characteristic and functions of a special purpose vehicle of project financing are presented. The conditions of project lending are described. The ways of ensuring financial stability of the investment and construction project at various stages of its life cycle are considered. At the preinvestment stage, the financial model and budget of the project are considered as a mechanism for ensuring the sustainability of the project. The directions of normative and methodological support for effective financial modeling and project budgeting in the context of project financing are identified. At the implementation stage, a cost control system for the investment and construction project was developed. A formal decomposition of the control system under study is proposed, and a functional description of the subjects of control is presented. The conditions of preserving the project within the budget and adaptive management of investment and construction projects are considered.
\end{abstract}

\section{Introduction}

Nowadays, project financing is an actual multi-tool form of financing investment and construction projects [1-8]. Money is not allocated on a state or corporate guarantee or property pledge, but on the cash flow that the project will generate. According to the forecasts of a number of scientists [7], an increase in the share of project financing by $1 \%$ due to the multiplier effect can lead to an increase in global GDP by $0.14 \%$.

At the same time, many experts emphasize that project financing in Russia is at the initial stage of development and has a number of problems [2-4, 6-8]. Russian banks cannot carry out project financing on the required scale for reasons of economic instability [3], the lack of sufficient reserves at banks, the high debt of Russian enterprises, etc. Significant factors hindering the development of project financing in Russia are the lack of the possibility for the project company to pledge future potential property and liability rights [7], underdeveloped mechanisms of state guarantees or refinancing of commercial banks for project financing transactions without using state guarantees. From the point of view of

\footnotetext{
* Corresponding author: mishlanova_m@mail.ru
} 
traditional lending, the project financing mechanism under consideration can be assessed as low-income and risky.

In modern conditions of transition to the principles of project financing, which has many implementation problems, a lot of attention should be paid to improving the management systems of investment and construction projects. The relevance of planning and controlling the creation of construction costs in the face of uncertainty, especially in the context of the establishment of project financing, is caused by the constant and objective influence of the risk of the need for funds to complete the construction in case of shortages and additional financing of the construction costs. In global practice, such risk and methods of managing the cost of an investment and construction project are poorly studied [9]. Among the methodological problems of the development of project financing in Russia, it is worth highlighting the underdevelopment of the institute of financial and economic expertise and monitoring the effectiveness and sustainability of investment and construction projects [1].

\section{Materials and methods}

Based on the purpose of this work, the author proposes to use an integrated holistic approach, since this study deals with various management systems and subjects, apply the principles of adaptive management, functional and structural approach, methods of decomposition of cost control tasks for investment and construction projects, structuring control functions, organizational design and regulation. The introduction of elements of a synergetic approach into the study will make it possible to predict, to a first approximation, the synergistic effect of the system for ensuring the financial stability of investment and construction projects.

\section{Results and discussion}

Specialized companies for project financing may take the form of a project company, an operator company, a development company, and a specialized developer. In the project financing model, the project company is a Russian legal entity that must be specially created to implement a specific investment project. The company charter should contain a provision that the sole subject of activity of the indicated legal entity is the implementation of the relevant investment project. The main goal of creating a company is a concrete separation of the project property, a clear direction and distribution of this property in order to implement the project and provide security to creditors.

Investment and construction projects undeniably comply with the requirements of the project financing model in terms of long-term, capital intensity, risk sharing, special use of funds, which involves specific signs of the implementation of the investment and construction project:

- technical and technological, economic, legal insulation of the investment and construction project,

- attribution of responsibility for a specific risk to a specific project participant with the condition of ensuring competence and effectiveness of activities

- targeted provision of project profitability,

- priority of project cash flow over assets, etc.

Investment project management is a set of organizational and control measures to ensure sustainability and effective achievement of goals throughout the project life cycle. Thus, the functions of the project company include communication between project 
participants, coordination and control of the project, ensuring the targeted use of funds, ensuring the effective implementation and financial stability of the project.

Under the stability of the investment and construction project, we can understand the property of the project to achieve the objective function in the given conditions with the given restrictions for the set time $[10,11]$. Formalization of the investment and construction project for the purposes of this study involves accepting value as a basic indicator of stability in the criteria set of indicators. In the formation of the project cost, it is necessary to distinguish the status "before implementation" and "in the process of implementation", when, in accordance with the life cycle, the cost and stability of the project change methodologically. From the standpoint of this study, the measure of stability is interpreted before implementation of the project as a margin of safety between the planned value of the variable parameter and its limit value, in the process of implementation - as the minimum acceptable deviation between the planned and actual value of the project parameter.

For the viability of project financing, guarantees of the financial stability of the investment and construction project and the fulfillment of contractual obligations for the distribution of cash flow are necessary. At the same time, there is a great need for lenders to provide complete and reliable information on the project, to monitor and develop contractual relations $[1,6]$ for ensuring the stability of the investment and construction project. The terms of the project lending should provide for the obligations of the project company [12], which provide the bank with control over the technical and economic parameters of the project, including preliminary coordination with the bank:

- basic conditions of the contract for participation in shared construction, including the minimum level of the selling price of premises, the minimum level of the average weighted selling price of the premises with a cumulative total, and the term for commissioning construction objects provided for by the general contract, which should exceed the term for putting the object into operation by at least three months;

- changes in project documentation affecting the technical and economic indicators of the project;

- changes in the construction period;

- changes to the terms and conditions of the general contract.

The terms of the lending should provide for provisions that ensure the bank's control with respect to the targeted use of funds:

- opening bank settlement account by a project company and making settlements only through it;

- coordination of the registry of payments with the bank prior to the issuance of each tranche of credit funds with confirmation of the volume and cost of the work performed and the validity of advance payments by construction experts of the bank or independent companies.

At the same time, subjective criteria must be added to the list of criteria ensuring the sustainability of project financing: capital structure and liquidity of the project company's assets, asset turnover, and project performance indicators. At the pre-investment stage, the procedures for ensuring the sustainability of the project should be based on financial modeling and budgeting of the investment and construction project. As a result of the formation of the financial model and the development of the project budget, the time series of financial indicators of the investment and construction project are determined. It is known that the cash flow of any investment project is a random process, the argument of which is time [11, 13]. Accounting for this random process in order to assess the sustainability of project financial indicators must be carried out on the basis of sensitivity analysis - an assessment of the degree of influence of key factors on the results of financial forecasts at the planning stage $[14,15]$. Key sensitivity factors include initial data, assumptions and limitations of the financial model, the actual values of which during the 
project implementation, due to the impossibility of their accurate assessment or their inherent volatility, can significantly deviate from the values inherent in the financial model: prices of finished products and tariffs for services; volume of production and sales, capacity utilization; delays in putting the investment object into operation and reaching its design capacity; prices of basic raw materials and supplies, fuel, labor force; delays in payments, the duration of the billing period, etc.

When predicting the effectiveness and sustainability of an investment and construction project in the context of project financing, it is worth considering the discount rate, which is an exogenously set economic standard for project efficiency. In the project financing model, the size of the premium for the risk of unreliability of project participants is determined taking into account the functions and obligations of each participant. The size of the amendment is reduced in the case of increasing the degree of guarantee of fulfillment of obligations, ensuring the completeness and reliability of information on the solvency and reliability of project participants, developing and implementing a system of insurance of functions, coordination and synchronization of project activities, and increasing transparency of project processes. The listed features are characteristic of atypical organizational and economic mechanisms, which allows identifying the range of adjustments for the risk of unreliability of project participants from $1 \%$ to $3 \%$, which is lower than for typical forms of investment project implementation [16].

The economic and mathematical essence of the stability analysis of an investment construction project involves assessing the expected average deviation of a certain factor and the obtained design result in the case of deviation of a variable from the base value. Based on the calculations performed, the ranking of factors by degree of importance is carried out. In each case, the possibility of predicting the dependence of the effective indicator of the project on the initial parameter is assessed. The indicated operations carried out at the pre-investment stage make it possible to take into account the basic principles of adaptive management in the investment and construction project management system, which will subsequently allow the development and implementation of a monitoring system for investment and construction projects.

Financial modeling and budgeting in the field of project finance should be normatively and methodologically provided. In this status, the field of development of project financing in order to achieve project sustainability by a set of indicators can be outlined as follows:

- improvement of the regulatory framework,

- development of templates and regulations for the financial model and project financing budget, taking into account the industry factor,

- development of methods for assessing and ensuring the financial stability of the project,

- formation of a set of methods for assessing and managing the cost parameters of the project,

- methodological development of multi-criteria assessment of project effectiveness,

- implementation of the adaptive project management system, formation of a database of project financing.

At the stage of implementation of the investment and construction project, there is an uncertainty of external and internal influences, which causes deviations of the parameters achieved during the implementation of the project from the planned ones [17]. At this stage of the project implementation, there can be the project budget overrun, which requires a change in the initial capital structure and risk sharing system: revision of lending parameters, additional issue of project company shares, issue of subordinated debt, change of investors, etc.

The evolving Russian practice of project management and cost management, among other things, reveals the facts of insufficient formalization of the management system, 
problems of goal conflicts, timing, resources, and reporting. Systematization and generalization of research and practical experience $[9,18]$, taking into account the specifics of developing project financing, make it possible to propose the following formalized decomposition of the control system under study (table 1).

Table 1. Functional decomposition of the cost control system of the investment and construction project.

\begin{tabular}{|c|c|c|}
\hline Functions & Basic tasks & Task decomposition \\
\hline \multirow{8}{*}{$\begin{array}{l}\text { Accounting } \\
\text { function - } \\
\text { provision of the } \\
\text { project with up- } \\
\text { to-date } \\
\text { information on the } \\
\text { actual progress of } \\
\text { the project and its } \\
\text { current state, } \\
\text { assessment of the } \\
\text { actual cost of } \\
\text { work performed } \\
\text { and resources } \\
\text { expended }\end{array}$} & \multirow{8}{*}{$\begin{array}{l}\text { Organization of } \\
\text { operational } \\
\text { monitoring and } \\
\text { reporting on } \\
\text { project progress }\end{array}$} & $\begin{array}{l}\text { Definition of target cost indicators of the project, key } \\
\text { criteria, benchmarks (a task coming from planning) }\end{array}$ \\
\hline & & $\begin{array}{c}\text { Organization of a system for collecting information and } \\
\text { reporting }\end{array}$ \\
\hline & & $\begin{array}{l}\text { Collection of information on the actual costs of the } \\
\text { work and assessment of the current state of the project }\end{array}$ \\
\hline & & $\begin{array}{l}\text { Determining the degree of project implementation by } \\
\text { cost indicators }\end{array}$ \\
\hline & & $\begin{array}{c}\text { Comparison of the actual costs of performing work with } \\
\text { the base ones. Analysis of deviations from the budget } \\
\text { and the causes of these deviations }\end{array}$ \\
\hline & & $\begin{array}{l}\text { Comprehensive control of spending and cash inflows, } \\
\text { identification of balance sheet imbalances }\end{array}$ \\
\hline & & $\begin{array}{l}\text { Analysis of factors influencing negative and positive } \\
\text { deviations, and possible consequences of these } \\
\text { deviations in the project }\end{array}$ \\
\hline & & $\begin{array}{l}\text { Preliminary calculation of the cost of future work of the } \\
\text { project based on the available actual information }\end{array}$ \\
\hline \multirow{6}{*}{$\begin{array}{l}\text { Corrective and } \\
\text { forecasting } \\
\text { functions - } \\
\text { provision of tools } \\
\text { for making } \\
\text { changes to the } \\
\text { project and } \\
\text { recalculation of its } \\
\text { main indicators, } \\
\text { assessment of the } \\
\text { future value of the } \\
\text { project }\end{array}$} & \multirow{6}{*}{$\begin{array}{l}\text { Project re- } \\
\text { planning system } \\
\text { and managing } \\
\text { deviations of } \\
\text { project cost } \\
\text { indicators from } \\
\text { budget ones }\end{array}$} & $\begin{array}{l}\text { Collection and processing of requests for changes in } \\
\text { project cost parameters }\end{array}$ \\
\hline & & $\begin{array}{l}\text { Preparation of recommended corrective actions to } \\
\text { eliminate unwanted deviations of project cost indicators }\end{array}$ \\
\hline & & $\begin{array}{l}\text { Predicting the status of the project according to the cost } \\
\text { after the implementation of management decisions } \\
\text { regarding design changes }\end{array}$ \\
\hline & & $\begin{array}{l}\text { Making decisions on regulatory impacts and changes to } \\
\text { the project. Performing corrective actions on the project } \\
\text { to reduce cost deviations }\end{array}$ \\
\hline & & $\begin{array}{c}\text { Change of plans, processes and procedures to prevent } \\
\text { possible further deviations of the project budget }\end{array}$ \\
\hline & & $\begin{array}{l}\text { Informing participants. Analysis and documentation of } \\
\text { changes made. Formation of a database of design } \\
\text { changes }\end{array}$ \\
\hline
\end{tabular}

In the cost control system of the investment and construction project, we propose to highlight internal subjective control and external control. In the processes of internal subjective control, the execution of control functions is carried out by the subject of creation of the added value of the controlled range (contractor). The task of organizing internal project control is to determine the need for input data and the frequency of reporting, forms and contents of reports, direct organization of the processes of regular collection and analysis of information. It should be emphasized the mandatory normative, methodological and practical compatibility of the above procedures and the regular activities of the economic entity. The frequency of control measures is determined on the basis of budget periods of both contracting work and periods of general budgeting, reporting, accounting and management accounting of the company. The formalization of the selected project reporting should reflect the state of the project in the form of controlled 
accounting and analytical indicators compared to the budget on the basis of common approaches and criteria, which dictates the requirements for reporting forms.

Besides, it is necessary to create a document management system and an appropriate functional structure, since the cost of any changes in the project must be calculated, agreed and documented. Based on the project cost management plan, those responsible for the implementation of financing and control of resources in the project or financial responsibility centers are appointed, their functional responsibilities, regulations, forms and contents of reporting are determined, methods for registration and presentation of actual data on costs in the project are determined. As a result of the analysis of the collected data, it becomes possible to determine whether the current situation corresponds to the planned one, if not, then determine the size of the deviations and their consequences.

General control by the project company involves comparing the actually completed work with a phased work plan for each contract. To do this, a contractor reporting regulation and a form for documenting changes should be developed. To maintain overall control over the cost of the investment and construction project, it is possible to recommend drawing up a register of contracts for this project taking into account the general controlled indicators and the total cost of services. If necessary, it is possible to differentiate this cost by type of work, by type of cost or time frame, by the total and differentiated amount of payments with taking into account the volume of accepted work.

Participants in investment and construction activities have various economic interests, which forms the specific requirements of the control assessment of the project cost. To increase the effectiveness of the implementation of investment and construction projects, it is advisable to involve independent specialized consultants who perform functions, among which the following can be distinguished:

- assessment of the reliability of price factors in the estimate documentation;

- supervision of the construction progress for compliance with contractual and actual design indicators;

- verification of the volumes and cost of the performed work, which are presented for payment by the construction and assembly organizations;

- prevention of overpayment of financial resources to the work performers on the basis of timely identification:

- verification of the cost of building materials presented for payment in acts of acceptance for compliance with average prices in the regional market;

- assessment of the volume of investment in construction in progress;

- keeping records of the volume and cost of poorly completed construction and assembly works, the costs of eliminating defects and alterations.

During the execution of the investment and construction project, the results and deviations from the planned indicators are determined in stages, measures for managing changes are developed, and potential results of their impact are determined. Thus, the results of the process of controlling the creation of the value of an investment and construction project are:

- assessment of the degree of compliance of indicators of the actual cost of the works on project with planned indicators,

- minimization of the project budget excess,

- lack of uncontrolled rise in price of work,

- management of changes in the cost of the project in order to reduce the negative aspects and increase the positive consequences of changes in the cost of the project,

- timely and effective elimination of the causes and consequences of deviations in the project budget.

In case of adaptive management $[19,20]$, the parameters of the investment and construction project are optimized and adjusted until the corresponding project goals are 
achieved in the current management cycle, and the stability of the investment construction project is restored. Ways to influence the sustainability of the investment and construction project in accordance with the principles of adaptive management involve:

- reduction of requirements for the objective function,

- increasing resource supply, creating reserves and increasing the interchangeability of resources,

- increasing the degree of maneuverability, weakening local restrictions,

- optimization of the design structure,

- creation of a core of elasticity, which takes on possible changes and is linked to consumers, resources, etc.

\section{Conclusion}

The effective implementation and maintaining the stability of the investment and construction project in the context of project financing requires the interactive use of financial modeling, budgeting, control of project parameters, cost forecasting, and the system of created value. The complex of measures proposed in the paper provides the basis for coordination of work and adaptive management of the investment and construction project. With a high-quality elaboration of the project, the threat of stability violation is reflected in the system of diagnosing the state of the project and developing opposing mechanisms, which allows restoring the stability of the ongoing investment and construction project in the context of project financing.

\section{References}

1. A.V. Alexandrov, A.I. Moskvicheva, Features of project financing in the domestic economy. Azimuth of scientific research: economics and management, 7, No. 3 (24), p.17-19 (2018)

2. P.G. Grabovy, M.A. Lunyakov, M.I. Kamenetsky, Features and problems of project financing. Real Estate: Economics, Management, No. 4, pp. 6-14 (2017)

3. A.I. Zakieva, Prospects for project financing of investment projects in Russia. Materials of IV scientific and practical conference "Problems of economics and management", pp.171-173, SPb. (2015)

4. V.V. Ivanter, On the problem of economic growth. Economic revival of Russia, No.2 (56), pp.14-16 (2018)

5. S.A. Molchanov, Fundamentals of project finance. Infotropic Media, p. 412 (2018)

6. I.A. Nikonova, A.L. Smirnov, Project financing in Russia. Problems and directions of development. "Konsaltibankir" Publishing house, p. 216 (2016)

7. Yu.G. Onoprienko, S.G. Margaryan, Areas for the development of project financing in Russia. Management. Business. Power, 1 (15), pp.113-117 (2018)

8. Yu. V. Pavkina, Problems of project financing in modern Russia. International Journal of Social and Human Sciences, 5, No. 1, pp. 29-32 (2016)

9. Churkin, V.I., Kalinina, O.V.: Estimation of excess burden of labor taxation in Russia, Actual Problems of Economics, 184(10), 278-282 (2016)

10. N.N. Grinchar, Assessment of the economic efficiency of investment projects by the criterion of economic stability. Universum: Economics and jurisprudence: electronic scientific j., No. 4 (37) (2017) http://7universum.com/en/economy/archive/item/4545

11. V.B. Chernov, V.A. Churyukin, Vestnik of SUSU, No. 27, pp. 45-49 (2007) 
12. Krymov, S.M., Kapustina, I.V., Kolgan, M.V.: Proc. of 2017 IEEE 6th Forum Strategic Partnership of Universities and Enterprises of Hi-Tech Branches (Science. Education. Innovations), SPUE 2017, 122-124 (2018)

13. D.V. Tikhomirov, The financial model as a decision-making tool in project finance. Izvestia of St. Petersburg State University of Economics, No. 2, pp. 44-51 (2018)

14. N.A. Kireeva, N.N. Luneva, T.M. Levina, The use of the sensitivity analysis method for assessing risks in investment projects, 2, No. 10, pp. 119-120 (2016)

15. E.N. Strelina, Vestnik of DonNU, Series B, Economics and law, No. 3, pp. 134-141 (2017)

16. M.Yu. Mishlanova, Review, 11, pp. 339-341 (2015)

17. Yakubu Adisa Olawale, Ph.D., Ming Sun COST AND TIME CONTROL OF Construction projects: inhibiting factors and mitigating measures in practice. Access mode:

http://publications.aston.ac.uk/id/eprint/15566/2/Cost_and time_control_inhibiting_fa ctors_and_mitigating_measures.pdf

18. L.V. Brezgina, D..V. Kamenskikh, Innovative development of building self-regulatory organizations, No. 7 (007), pp. 23-31 (2017)

19. A.V. Melekhin, Organization of adaptive management of construction projects. Management of economic systems: electronic scientific journal, No. 12 (36), pp. 51(2011)

20. Kozlova, N., Jacobsen, B., Golovkina, S., Kupriyanova, M.: IOP Conference Series: Materials Science and Engineering, 497(1), 012122 (2019) 